\title{
Examples of Constructions with the Simple Topological English Prepositions in and at Expressed in Selected Slavic Languages
}

\author{
Dorota ChŁopek \\ Univerza v Bielskem-Biali, Fakulteta za humanistiko in družbene vede, Ul. Willova 2, \\ PL-43-309Bielsko-Biała,dorotach@ath.bielsko.pl
}

\begin{abstract}
SCN II/1 [2009], 59-72
$\mathrm{V}$ razpravi so analizirane izbrane zgradbe značilnih angleških predlogov in ter at, ki so navzoči v slovanskih jezikih, kot so poljščina, češčina, slovenščina, srbščina oziroma hrvaščina. Običajni odnosi, ki se $\mathrm{v}$ angleškem jeziku določajo $\mathrm{z}$ dvema predlogoma: (1) in, npr. be in thela restaurant, (2) at, npr. be at the restaurant, so v posameznih slovanskih jezikih izraženi z eno obliko. Nerazlikovanje mesta teh predlogov pri prevodu iz angleščine lahko povzroča težave pri prevajanju v slovanske jezike.

The objects of study in this paper are selected English expressions with the simple topological prepositions in and at expressed in the following Slavic languages: Polish, Czech, Slovene, Serbian and Croatian. Simple locational, topological relations which the English language encodes through two separate prepositions in and at tend to be constructed by a single form in many Slavic languages. The concerns of the paper are selected English constructions expressing physical coincidence through in and functional coincidence through at, rendered into the five Slavic languages, where the scenes may not include the difference in dimensionality existing in the source expressions, which causes many translational problems.
\end{abstract}

Ključne besede: topološke zgradbe, predlogi, lokacije, funkcionalna skladnost, prevajanje

Key words: topological constructions, prepositions, locational, functional coincidence, translation

The objects of study in this paper are selected constructions with the verb to be and two simple topological English prepositions, the prepositions in and 
$\underline{a t}$ respectively, with $\underline{a t}$ used only in its topological sense. These topological prepositions can precede the names of buildings in coincidence relations; moreover, they can occur before the names of institutions in separation relations. The situations denoted by the verb to be with the prepositions in and $\underline{a t}$ respectively are expressed in the Polish, Czech, Slovene, Serbian and Croatian languages in this paper.

There are only two basic relations which are profiled by spatial prepositions in English, following Hawkins, COINCIDENCE and SEPARATION. Hawkins explains that /.../ the specifically relational content of any spatial preposition in English can be identified as either COINCIDENCE or SEPARATION (Hawkins 1993: 329). Coventry and Garrod assert that /.../, whereas there are cases such as 'The man being at the piano', in which the man is both spatially localised at the piano and interacting with it, there are also cases, such as 'The man being at the window' or 'The woman at the supermarket', where located and reference objects do not have to coincide spatially (2004: 118). In this paper, at and in respectively are referred to as simple topological prepositions denoting location. According to O'Keefe, the preposition at also belongs to the group of omnidirectional prepositions (1996: 299), which is demonstrated by usages like be at the piano or be at the door, etc. However, the preposition $\underline{a t}$, following Brala, expresses functional coincidence in the context presented here. This type of coincidence occurs in situations lexicalized by $\underline{a t}$ with the following referents: factory, theatre, cinema, church, prison, hospital, supermarket, hotel, restaurant, office, etc. The paper does not relate the preposition at to its other realizations connected with the coincidence of being located with respect to a point-like object, which means that the paper does not deal with simple locational coincidence, directional coincidence or temporal coincidence (c.f. Brala 2000). It focuses exclusively on functional coincidence expressed by at.

The object of location preceded by at is perceived as a point-like "institution" serving a particular function in the further examples. The prepositions $\underline{i n}$ and at often cause problems when it comes to translation practices. I concentrate on the usage of several referents which can be conceptualized either as threedimensional buildings through the presence of $\underline{i n}$, or as point-like "institutions" due to the usage of the preposition $\underline{\text { at }}$. Therefore, in this paper, the prepositions $\underline{i n}$ and $\underline{a t}$ respectively denote only one type of relation out of many possible configurations connected with their different senses.

For many speakers of Slavic languages, the conceptualization problem arises with different senses of English prepositions - called distinct senses (c.f. Tyler, Evans 2003) - which cannot be inferred from context or related to other senses of the particular lexical item. Distinct senses are encoded within the same lexical category, which confuses learners of English and to a significant degree complicates communicating spatial relations expressed by English prepositions to many users of Slavic languages. The basic condition to be fulfilled in order to comprehend the usage of English prepositions in all their senses, distinct and polysemous, is to understand the basic scenes they evoke, and the most common configurations they construct, which are called proto-scenes (c.f. Tyler, 
Evans 2003) for the given prepositions. Each preposition has one proto-scene, the best example of all spatial configurations denoted by that preposition. The prototypical locational use of in and the functional coincidence encoded through at expressed in Polish, Czech, Slovene, Serbian and Croatian are the subjects of this paper. The relations constructed by these forms respectively (locational for $\underline{i n}$ and functional for $\underline{a t}$ ) tend to be encoded through single lexical items in many Slavic languages. Therefore, these single lexical items can be confusing, particularly with English as the destination language in the translation process.

Spatial scenes are constructed in various ways across natural languages. The prepositions in and at limit the variety of spatial constructions to those without factive motion (c.f. Talmy 2000) prescribed to them, i.e. with no real motion encoded in their prototypical sense. The senses of the prepositions in and $a t$, communicating containment in a building and location at an "institution" respectively, tend to have one equivalent form in the Slavic languages under consideration here: the preposition $\underline{w}$ in Polish, $\underline{v}$ in Czech, $\underline{v}$ in Slovene, $\underline{u}$ in Serbian, and $\underline{u}$ in Croatian. That is why the English prepositions in and $\underline{a t}$ with reference to one object can very often confuse users of many Slavic languages. The objectives of the paper are to demonstrate certain regularities in using the senses of the English prepositions: $i n$ denoting location in buildings, and at implying function, activity or interaction with respect to particular "institutions", and to relate these two prepositions respectively to the equivalent constructions encoded through prepositions in the destination Slavic languages. The paper gives a general outline of the spatial scenes created by $\underline{i n}$ and $\underline{a t}$ respectively in the source language and by $\underline{w}, \underline{v}$, and $\underline{u}$ in the destination languages.

Before analysing the proto-scenes for both prepositions (in and $\underline{a t}$ ), definitions for the senses under consideration in this paper are listed below from an Internet lexicon: www.thefreedictionary.com. Then, the particular scenes denoted by $\underline{i n}$ and $\underline{a t}$ respectively are contrasted intralinguistically, with reference to the English language. Subsequently, it is shown how they are conveyed in the Slavic languages under consideration here - this contrast is interlinguistic. The following situations are compared (intra and interlinguistically): (1) in the factory, $\underline{a t}$ the factory, (2) in the theatre, $\underline{a t}$ the theatre, (3) $\underline{i n}$ the cinema, $\underline{a t}$ the cinema, (4) in the church, at the church, (5) in the/a/ø prison, at Trenton/ the/a prison, (6) in the/a/ø hospital, at Harefield/the/a/ø hospital, (7) in the/a supermarket, at Tesco/the/a supermarket, (8) in the/a hotel, at the Hilton (hotel), (9) in the/a restaurant, at the/a/Moosewood restaurant, and (10) in the/an office, $\underline{\text { at }}$ the/his, my etc office.

In one of the Internet lexicons, ${ }^{2}$ the prepositions: I. $\underline{i n}$, II. $\underline{a t}$ are given the following definitions for the senses relating to buildings (the preposition $\underline{\mathrm{in}}$ ) and functions performed by analogical "institutions" (the preposition $\underline{a t}$ ), in

\footnotetext{
${ }^{1}$ The symbol "ø" is a technical term for "no article here".

${ }^{2}$ Cf. [URL:http://www.thefreedictionary.com/on] The Internet dictionary provides the option to translate the entry item into the selected language. The equivalent is not italicised or underlined in the original version.
} 
the following Slavic languages: a) Polish, b) Czech, c) Slovene/Slovenian, d) Serbian, e) Croatian:

I. prep in [in] sense 1 describing the position of a thing etc which is surrounded by something else $M y$ mother is in the house; in London; in bed.

a) Polish: $\underline{w}$; b) Czech: $\underline{v(e)}$; c) Slovene: $\underline{v}$; d) Serbian: $\underline{u}$; e) Croatian: $\underline{u}$

\section{II. prep at [æt]}

sense 1 describing position They are not at home; She lives at 33 Forest Road.

a) Polish: $\underline{w}, \underline{p r z y}$; b) Czech: $\underline{v(e)}$; c) Slovene: $\underline{v}, \underline{n a}$; d) Serbian: $\underline{k o d}, \underline{u}$; e) Croatian: $\underline{k o d}$ sense 4 describing the state or occupation The countries are at war; She is at work.

a) Polish: $\underline{w}$ (stanie); b) Czech: $\underline{v(e)}$; c) Slovene: $\underline{v}, \underline{n a}$; d) Serbian: $\underline{u}, \underline{n a}$; e) Croatian: $\underline{u}, \underline{n a}$

The prepositions in and at can be easily confused by many native users of Slavic languages because, as shown in the usages above, they may have the same equivalents - in this case $\underline{w}$ for Polish, $\underline{v / e}$ for Czech, $\underline{v}$ for Slovene and $\underline{u}$ for Serbian and Croatian respectively.

Using a preposition or spatial particle is connected with the proto-scene for the form in question. That claim follows a commitment of Tyler and Evans, according to whom /.../ the speakers attribute new meanings to a specific lexical item due to perceiving the new meaning to be related to a meaning already conventionally associated with the particular form, /.../ (Tyler, Evans 2003: 64). What we term proto-scene is an /.../ abstracted mental representation of the primary sense (Tyler, Evans 2003: 65). According to a widely accepted cognitive assumption, the physical-spatial nature of a proto-scene is extended to nonspatial situations. Tyler and Evans present the opinion that /.../ there may be different construals of a scene that result in multiple motivations for an extended sense (2003: 63).

The first preposition - in - has one ideal meaning, it expresses the relation of INCLUSION, requiring its second argument to refer to a COMPLETELY BOUNDED THREE-DIMENSIONAL entity. Around this, all derived senses center by exploiting and transforming the ideal meaning in different ways (ZelinskyWibbelt 1993: 364). The preposition in is connected with the concept CONTAINER, one of the three rudimentary concepts: CONTACT, CONTAINER and BALANCE (c.f. Johnson 1987). Mandler ([in:] Evans, Green 2007: 46) suggests that the CONTAINER image schema or concept /.../ is more than simply a spatio-geometric representation. It is a 'theory' about a particular kind of configuration in which one entity is supported by another entity that contains it. In other words, the CONTAINER schema is meaningful because containers are meaningful in our everyday experience. Tyler and Evans define the containment function, which is involved in the spatial scene constructed by $\underline{i n}$, as encompassing several consequences such as locating and limiting the activities of the contained entity (2003: 63). Although for this reason the preposition in can denote scenes that are non-spatial in nature, e.g. He is in trouble, the subject of this paper puts the preposition in in real or factive situations. The 
containment function of $\underline{i n}$ is performed by physical entities - buildings - in these situations. While the prepositional expression in the house, where house is idealised as a box, expresses an ideal inclusion, in the prepositional expression in London, in the example from thefreedictionary.com shown above, the preposition in /.../ is semantically related to the prototypical relation: London is idealized as a TWO-DIMENSIONAL AREA and thus can only provide a PARTIAL ENCLOSURE. Yet the relation of INCLUSION holds, although in a less typical way (Zelinsky-Wibbelt 1993: 364). In this paper, the focus is put only on the prototypical sense associated with $\underline{i n}$, with a boundary, which in part distinguishes between interior and exterior (Tyler, Evans 2003: 196).

The second English preposition used in this paper for contrasting the entity's location by the purpose of the relational expression, $\underline{a t}$, as in the sentence She lives at 33 Forest Road, following Zelinsky-Wibbelt, only indicates the COINCIDENCE of the position of her house with that of the road (1993: 360). ${ }^{3}$ On the basis of Zelinsky-Wibbelt's comment, the preposition at instantiates the projection of the house to a ZERO-DIMENSIONAL point and that of the road to a ONE-DIMENSIONAL line respectively. This sentence will not necessarily be uttered with a travelling event in mind, that is the speaker is not mentally near to the spatial scene (1993: 361). Based on this statement and looking at other referents in the examples above, e. g. home in the expression at home and work in the expression $\underline{a t}$ work, $\underline{a t}$ is relatively vague about location, which is some physical place, and more specific about activity (Lindstromberg 1997: 168), like with e.g. the referents used in the prepositional expressions presented below. Cienki formulates the same idea in another way. At is more common when the function rather than the material aspect of the institution is uppermost in the speaker's mind (1989: 107). Following Lindkvist, ${ }^{4}$ Cienki adds that /.../ at is often used rather than in when the locality is referred to by its proper name rather than by a common noun, e.g. in the restaurantlat the Ritz /.../ (1989: 107). Cienki bases his research upon contrasting English with Polish and Russian. The latter Slavic language is not included in the examples here. Since this paper deals with three-dimensional objects, with reference to which the preposition at implies COINCIDENCE, quoting Cienki, in such contexts, at /.../ usually corresponds to $P \underline{n a}$ or $\underline{w}+L$ and $R$ na or $\underline{v}+L$. Na is common with L-rs schematized as two-dimensional /.../ (1989: 110). P stands for the Polish language, $R$ symbolizes the Russian Language and $L$ substitutes the parameter Landmark (Landmarks $=L-r s)$. The notions Landmark and Trajector were used by Langacker (1987: 217-220). Those parameters constitute the configurational elements of a spatial scene. Trajector (TR) /.../ is the locand (i.e., the element located) and is typically smaller and movable; a landmark (LM), which is the locator (i.e., the element with respect to which the TR is located) and is typi-

\footnotetext{
${ }^{3}$ Originally not a house but a gas station.

${ }^{4}$ Karl-Gunnar Lindkvist, 1978: AT versus ON, IN, BY: On the Early History of Spatial AT. Stockholm: Almqvist \& Wiksell.
} 
cally larger and immovable /.../ (Tyler, Evans 2003: 50). Cienki states that /.../ $P \underline{w} / R \underline{v}$ are of course also used with three dimensional L-rs: at school: $P \underline{w}$ szkole: /.../ (1989: 110).

Although - according to Cienki - Slavic lacks a semantic counterpart for at, there is a tendency in Russian and particularly in Polish (and perhaps in other Slavic languages) to use na to indicate general direct location (1989: 111). He refers to Sysak-Borońska, ${ }^{5}$ who /.../ notes a tendency that has grown since the 1960's in colloquial Polish to use na to indicate general direct location. This is particularly the case with reference to places of work. This is understandable in reference to buildings and institutions /.../ (Cienki 1989: 111). However, as far as the first two examples quoted by Cienki to illustrate this opinion are concerned: $P$ Mój tata pracuje na fabrycel na huciel /... 'My dad works at/*6 literally: on the factory/ at/*literally: on the mills /.../' (Cienki 1989: 111), we read in the fabryka entry of Wielki stownik poprawnej polszczyzny PWN, Part A-P: Pracować $w$ fabryce (nie: na fabryce), 'Work at/(literally: in) the factory (not: *literally: on/(at) the factory)'. Ale: Kierownik jest teraz pot. na fabryce, lepiej: na terenie fabryki (c.f. 2006: 252), But: 'The manager is coll. at/(*literally: on) the factory now, better: on the premises of the factory.' A similar issue can be noted in connection with the huta entry of the same lexicon, Part A-J: Pracować w hucie (nie: na hucie) (2006: 329), 'Work at/(literally: in) the mills (not: *literally: on/(at) the mills)'. Corresponding comments concerning the above entry words were given in another dictionary of proper usage in Polish which was edited by Doroszewski and published in $1973 .{ }^{8}$ Nevertheless, it should also be pointed out that four years earlier, with Doroszewski on the editorial committee, Szober considered być na fabryce, 'be at/(*literally: on) the factory' $=w$ jakimś dziale, 'at some departament' appropriate formal Polish. He also indicated: pracować w fabryce [nie: na fabryce] (Szober 1969), 'work at/literally: in the factory [not: *literally: on the factory]. The formal Polish language, however, uses the preposition $\underline{w}$ with reference to factory conceptualized both: as a three-dimensional location to "hide" (containment) and as a zero-dimensional place to "work" (activity) respectively. To justify this usage, one may speculate that the referents factory ${ }^{9}$ and mills (or: ironworks ${ }^{10}$ ) are

\footnotetext{
${ }^{5}$ Maria Sysak-Borońska, 1980: The Spatial System in English and Polish: Prepositions of Direct Location. Ph. D. dissertation. Katowice, Poland: University of Silesia, p. 70.

${ }^{6}$ an asterisk '*' implies incorrect usage

${ }^{7}$ Example (3.75)

${ }^{8}$ fabryka /.../ Pracować w fabryce (nie: na fabryce). pot. Dyrektor jest w tej chwili na fabryce (lepiej: na terenie fabryki), p. 160 and huta /.../ Pracować w hucie (nie: na hucie) /.../, p. 207.

${ }^{9}$ a. A building or group of buildings in which goods are manufactured; a plant. Cf. [URL: http://www.thefreedictionary.com/factory] (originally "A building" is not in bold)

${ }^{10}$ a building in which iron is smelted, cast, or wrought Cf. [URL: http://www.thefreedictionary.com/ironworks] Collins Essential English Dictionary 2nd Edition 2006 C HarperCollins Publishers 2004, 2006
} 
entrenched as three-dimensional objects in our minds, unlike another referent of a place of work- quarry $y^{11}$ or delf ${ }^{12}$, which implies an open excavation. Also, with reference to e.g. Polish coal mines, a mine ${ }^{13}$ involves all the coal processing stages which take place on the surface of that place of work. Therefore, perhaps, the third example provided by Cienki: P Mój tata pracuje /.../ Ina kopalni 'My dad works /.../ at the mine' (1989: 111) is considered correct among the mining community by Wielki słownik poprawnej polszczyzny $P W N$, Part $A-P$ : Pracować w kopalni, środ. górn. na kopalni (2006: 430) 'Work at/literally in the mine, the mining community: at the mine (literally *on the mine).

A similar issue concerning the referent factory can be observed in the case of formal Czech, Slovene, Serbian, and Croatian, where the prepositions correlating with the Polish $\underline{w}-\underline{v}$ and $\underline{u}-$ are used. Moreover, the prepositions $\underline{v}$ and $\underline{u}$ correlate with the Polish preposition $\underline{w}$ in the situations from (1) to (10), and probably in many other ones. The Polish prepositional expressions $\underline{w}+$ loc (with loc = fabryce 'factory', teatrze 'theatre', kinie 'cinema', kościele 'church', więzieniu 'prison', szpitalu 'hospital', supermarkecie 'supermarket', hotelu 'hotel', restauracji 'restaurant', biurze 'office', etc) denote a subscheme parallel to the prototypical scheme, e.g. to the "best" example of using $\underline{w}$, which is - following Przybylska - a relation with the Trajector (an object) and the Landmark idealized as a three-dimensional container. The researcher notes that $\underline{w}+$ loc contrasts with the relations expressed by the other preposition $\underline{n a}+$ loc, which she illustrates with the following examples: Kredki sa w pudełku and Kredki sa na pudetku, 'There are crayons in the box' and 'There are crayons on the box'. The sentences bring out the semantic contrast connected with localization within the interior region of a Landmark and with localization in the exterior region of a Landmark. As far as the topological aspect is concerned, the Polish preposition $\underline{w}$ informs us that the spot of localization of the Trajector is the interior region of the Landmark (2002: 206). Przybylska notes that apart from a typical box, etc, also a room, a house, a café, a store, a theatre, a cinema, a church, a car, a tram, a wagon, that is to say different rooms, buildings, huge vehicles or parts of buildings are conceptualized as the central or main ones in relation to other parts (2002: 210). She also points to the fact that the speaker will use the preposition $\underline{w}$ when he wants to bring out the Landmark having the function of a container which protects the located object from the sight of a potential observer. However, if on the other hand, it is important that the Landmark be used as a support for the located Trajector, with the major part of the latter being visible to the exterior observer, then the preposition $\underline{n a}$ is appropriate (2002: 210).

${ }^{11}$ An open excavation or pit from which stone is obtained by digging, cutting, or blasting. Cf. [URL: http://www.thefreedictionary.com/quarry+] (originally »a building « is not in bold)

${ }^{12}$ A mine; a quarry; a pit dug; a ditch. Cf. [URL: http://www.thefreedictionary.com/delf]

${ }^{13} \mathrm{~b}$. The site of such an excavation, with its surface buildings, elevator shafts, and equipment. Cf. [URL: http://www.thefreedictionary.com/mine] 
On the basis of these observations, several container type referents - buildings from (1) to (10) - are associated with $\underline{w}+$ loc, $\underline{v}+$ loc, $\underline{u}+$ loc when they imply location in a container type object. The same prepositions, and in the majority of cases ${ }^{14}$ prepositional expressions ( $\underline{w}+$ loc, $\underline{v}+$ loc, $\underline{u}+$ loc), are used when the scene implies functional coincidence, activity or social interaction, which the English language encodes through the preposition $\underline{a t}$.

(1) in the factory

Polish: $w$ fabryce

Czech: $v$ podniku / $v$ továrně

Slovene: $v$ tovarni

Serbian: $u$ fabrici

Croatian: $u$ tvornici

$a t$ the factory
$w$ fabryce
$v$ podniku / $v$ továrně
$v$ tovarni
$u$ fabrici
$u$ tvornici

$\underline{a t}$ the factory

$w$ fabryce

$v$ podniku / $v$ továrně

$v$ tovarni

$u$ tvornici

Looking at the further examples (2) - (10) one can notice a certain regularity in the five Slavic languages. The preposition at does not have a semantic counterpart in any of the Slavic examples. While English carries much spatial information not only through the prepositions themselves, $\underline{i n}$ and $\underline{a t}$ respectively, but also through the articles $a$, the or zero, many Slavic languages reduce the semantic value to a universal expression with the prepositions $\underline{w}, \underline{v}$, or $\underline{u}$. What information can be omitted this way is commented upon below.

The examples (2) and (3) include similar spatial scenes: on the left, there are three-dimensional buildings with a label 'theatre' and 'cinema' in (2) and (3) respectively, and on the right, there are zero-dimensional "institutions" functioning as 'theatre' and 'cinema'. This distinction is conveyed by the preposi-

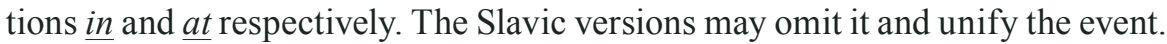

(2) in the theatre

Polish: $w$ teatrze

$\underline{a t}$ the theatre

Czech: $v$ divadle (v budově)

$w$ teatrze

Slovene: $v$ gledališču

$v$ divadle

Serbian: $u$ pozorištu

$v$ gledališču

Croatian: $u$ kazalištu

$u$ pozorištu

$u$ kazalištu

(3) in the cinema

Polish: $w$ kinie

at the cinema

Czech: $v$ kině (v budově)

Slovene: $v$ kinu

$w$ kinie

$v$ kině dávají / hrají zajímavý film

$v$ kinu

Serbian: $u$ bioskopu

Croatian: $u$ kinu

$u$ bioskopu

$u$ kinu

Used as examples, several English prepositional expressions without the articles $a$ and the preceding the noun phrase, e.g. in prison (=being in prison as a prisoner), in hospital (=being in hospital as a patient), and at church (=being there to pray), are more specific about activity (Lindstromberg 1997: 168). When the preposition $a t$, followed by either of the two articles ( $a$ or the), precedes the

\footnotetext{
${ }^{14}$ In the example (10) Slovene uses the same preposition $v$ with different post-prepositional noun phrases - see (10) below.
} 
notion prison, the location is conceptualized as a zero-dimensional 'institution' e.g. to work for as in extract 1) below, or to perform some other activity than 'serve time' e.g. to riot as in extract 2) below. Thus, at Trenton/a/the prison may imply some long term process or event (other than 'being imprisoned') taking place on the premises of a prison conceptualized as an area belonging to an institution labelled "prison", as in the two examples: 1) In August 1864 Major John H. Gee was appointed to the post as commandant and was the best known of all the commandants to serve at the Salisbury Prison. Although Gee's stay at the prison was a short stay, he was the only commandant indicted and tried for alleged mistreatment of the prisoners. $/ . . /{ }_{15}^{15}$ 2) Dozens of criminals who rioted for two days at a high-security prison in Australia have been persuaded to surrender. ${ }^{16}$

As far as another 'institution' is concerned, church, Lindstromberg indicates that /.../ being 'in althe church' means being within the walls of the church, not outside in the church yard. As to activity, 'in' is wholly nonspecific. One might, for example, be participating in a service or just sightseeing. 'At [a/the] church', on the other hand, is relatively vague about location and (when the article is absent) more specific about activity. Thus, to be 'at althe church' means that one is on church premises, perhaps inside the building, perhaps outside. There is a strong implication that one is participating in some kind of recognized church activity (1997: 168). Lindstromberg recommends that we note that the prepositional expressions at althe church/office/school, with a or the following at, the implication of 'recognized church/office/school activity' disappears. He adds that at althe church /.../ is something one might say (instead of 'in althe church') when it is not important to be precise whether someone is actually inside the church building or, for example, in the church yard (1997: 169). Moreover, at is often used when the locality is referred to by its proper name (Cienki 1989), e.g. at St Agnes (church).

None of the five Slavic languages under consideration here gives rise to such deliberations through using the preposition realised as $\underline{w}, \underline{v}$, and $\underline{u}$ to denote the scenes constructed by $\underline{i n}$ and $\underline{a t}$ respectively, without any articles following them. The noun phrase as the locativus does not appear to have the function of the English articles: $a$, the, zero $=\varnothing$.

(4) in the/a church

Polish: $w$ kościele

Czech: $v$ kostele

Slovene: $v$ cerkvi

Serbian: $u$ crkvi

Croatian: $u$ crkvi

$\underline{a t}$ St Agnes/the/a/ ø church
$w$ kościele
$v$ kostele
$v$ cerkvi
$u$ crkvi
$u$ crkvi

${ }^{15}$ [URL: http://www.gorowan.com/salisburyprison/]

16 [URL: http://news.sky.com/skynews/Home/World-News/Riot-At-Port-Augusta-PrisonInmates-Angry-At-Overcrowding-And-Poor-Conditions/Article/200810215117616?f=rss] 
(5) in the/a/ø prison

Polish: $w$ więzieniu

Czech: ve vězení

Slovene: $v$ zaporu

Serbian: $u$ zatvoru

Croatian: $u$ zatvoru

(6) $\underline{\text { in the/a/ø hospital }}$

Polish: $w$ szpitalu

Czech: $v$ nemocnici

Slovene: $v$ bolnišnici

Serbian: $u$ bolnici

Croatian: $u$ bolnici

\author{
at Trenton/the/a prison \\ $w$ więzieniu \\ ve vězení \\ $v$ zaporu \\ $u$ zatvoru \\ $u$ zatvoru \\ at Harefield/the/a/ø hospital \\ $w$ szpitalu \\ $v$ nemocnici \\ $v$ bolnišnici \\ $u$ bolnici \\ $u$ bolnici
}

Yates enumerates several referents before which the preposition at can indicate location. The notions: factory, hospital, store or mall (here: supermarket), hotel, restaurant, office, and theatre are included in the list of nouns commonly used with the following pattern: The women are at the supermarket (1999: 20). The Landmark or object of reference $y$ is seen as a point in this pattern (Hewings 1999: 208). Coventry and Garrod follow Miller and Johnson-Laird's approach. They note that /.../ it is not necessary to be contiguous /.../ or juxtaposed to something in order to be 'at' it. For a located object ' $x$ ' to be 'at' a reference object ' $y$ ' requires that the located object ' $x$ ' is included in a region of the reference object ' $y$ ' where it can 'interact with ' $y$ ' socially, physically or in whatever way 'x's' normally interact with 'y's"' (2004: 118). This point of view stretches the contiguity statement referring to $\underline{\text { at }}$ commented upon at the beginning of the paper. None of the five Slavic languages seems to express the subtle differences between containment and "social interaction" in an equivalent way with the English constructions.

(7) in the/a supermarket

Polish: $w$ supermarkecie

Czech: $v$ supermarketu

Slovene: $v$ veleblagovnici

Serbian: $u$ hipermarketu

Croatian: $u$ supermarketu

(8) $\underline{\text { in }}$ the/a hotel

Polish: $w$ hotelu

Czech: $v$ hotelu

Slovene: $v$ hotelu

Serbian: $u$ hotelu

Croatian: $u$ hotelu

(9) in the/a restaurant

Polish: $w$ restauracji

Czech: $v$ restauraci

Slovene: $v$ restavraciji

Serbian: $u$ restoranu

Croatian: $u$ restoranu at Tesco/the/a supermarket

$w$ supermarkecie Tesco

$v$ supermarketu Tesco

$v$ veleblagovnici Tesco

$u$ hipermarketu Tesco

$u$ supermarketu Tesco

at the/ø Hilton

$w$ Hiltonie

$v$ Hiltonu

$v$ Hiltonu

$u$ Hiltonu

$u$ Hiltonu

at the/a/Moosewood restaurant

$w$ restauracji

$v$ restauraci

$v$ restavraciji

$u$ restoranu

$u$ restoranu 
Similarly, to be in one's office - quoting Lindstromberg - means just that one is within its walls. As to activity, one might be working or doing a crossword puzzle. To say that someone is at the office is less precise about location. It can still be a true statement if the person concerned is wandering in and out of their office, to the photocopier and back, for example (1997: 169). However, when the article disappears and someone is in office, then the reading is different from the previous two, namely: in or out of office (of a government) in or out of power [Latin officium service, duty]. ${ }^{17}$

(10) $\underline{\text { in }}$ the/an office

Polish: $w$ biurze

Czech: $v$ kanceláři / $v$ úřadě

Slovene: $v$ pisarinó

Serbian: $u$ birou

Croatian: $u$ birou

$\frac{a t}{w}$ the/my, your, his etc office ${ }^{18}$
$v$ kanceláři $/ \mathrm{v}$ úřadě
$v$ službó
$u$ birou
$u$ birou

The last English example with the preposition $\underline{a t}-(10)-$ is illustrated with sentences 3) to 6 ). The examples 1 ) to 6) contextualize the selected prepositional expressions with different readings, for which the Slavic versions make use of $\underline{w}+$ loc, $\underline{v}+$ loc, and $\underline{u}+$ loc.

3) George Worsley Adamson Working Late at the Office: /.../ 19

4) Appearance at immigration office" is similar to "surrender" in the criminal procedures. It means that foreign nationals that fall under the conditions as stated in Article 24 of the Immigration Control Act voluntarily appear at regional immigration bureau and declare their charges. ${ }^{20}$

5) John Song called 911 at 1 p.m. Friday when his ex-wife appeared at his office, also in the 3600 block of 20th Street, and was causing a commotion with patients in the waiting room, according to the affidavits. ${ }^{21}$

6) Now, as he spends his last months in office trying to avert a global economic collapse, Mr. Bush has been telling people privately that it's a good thing he's in charge. ${ }^{22}$

Apart from the distinction in the Slovene language between $v$ pisarinó and $v$ službó, where the same preposition $\underline{v}$ precedes a different noun phrase, all of the scenes which English encodes as the prepositional expressions with the heads $\underline{i n}$ or $\underline{a t}$, with or without articles $(a$, the, $\varnothing)$, may be expressed with a preposi-

${ }^{17}$ Cf. [URL: http://www.thefreedictionary.com/office]

${ }^{18}$ Also: at the/ø box office (entertainment): While the movie has received lukewarm response at the box office, on last count the film was available on over six different portals of which Businessofcinema.com is aware. /.../ Cf. [URL: http://businessofcinema.com/ news.php?newsid=10310]

${ }^{19}$ Cf. [URL: http://occmed.oxfordjournals.org/cgi/content/citation/58/7/456]

${ }^{20} \mathrm{Cf}$. [URL: http://www.immi-moj.go.jp/english/tetuduki/taikyo/ihan.html]

${ }^{21}$ Cf. [URL: http://www.tcpalm.com/news/2008/oct/20/argument-medical-office-getsvero-beach-doctor-ex-/]

${ }^{22}$ Cf. [URL: http://www.nytimes.com/2008/10/11/business/11bush.html] 
tion implying one prototypical relation - the relation of containment. Thus, a conceptualiser of either scene - that denoted by $\underline{i n}$ or that encoded through $\underline{a t}$ - requires more data to construe the spatial relation, e.g. the situational context and some background knowledge about the given situation; also associating facts and logical thinking may be useful, which means that a lot of extralinguistic substance is applied to such conceptualizations. The distinction between physical coincidence related to in with reference to buildings and functional coincidence or 'interaction' connected with $\underline{a t}$ with reference to 'institutions', together with the information included in the presence or absence of articles, disappears in the scenes expressed in the Slavic languages taken into consideration in this paper. The Slavic prepositional expressions (1) - (10) include general information, without specifying the physical nature or functional role of the whereabouts of the object, which may cause problems with expressing the function of the 'institution' in translations into English.

\section{BIBLIOGRAPHY}

Marija M. BRALA, 2000: Understanding and translating (spatial) prepositions: An exercise in cognitive semantics for lexicographic purposes. [URL:http://www. rceal. cam.ac.uk/Publications-/Working/Vol7/Brala.pdf]

Alan J. CIENKI, 1989: Spatial Cognition and the Semantics of Prepositions in English, Polish, and Russian. München: Verlag Otto Sagner.

Kenny R. COVENTRY, Simon C. GARROD, 2004: Saying, Seeing and Acting: The Psychological Semantics of Spatial Prepositions. Hove, East Sussex: Psychology Press.

Witold DOROSZEWSKI, Halina KURKOWSKA. Eds., 1973: Stownik poprawnej polszczyzny. Warszawa: PWN.

Vyvyan EVANS, Melanie GREEN, 2007 (2006): Cognitive Linguistics. An Introduction. Edinburgh: Edinburgh University Press.

Bruce W. HAWKINS, 1993: On universality and variability in the semantics of spatial adpositions. The Semantics of Prepositions. From Mental Processing to Natural Language Processing. Ed. Cornelia Zelinsky-Wibbelt. Berlin/New York: Mouton de Gruyter. 327-349.

Martin HEWINGS, 1999: Advanced Grammar in Use. Cambridge: Cambridge University Press.

Mark JOHNSON, 1987: The Body in the Mind: The Bodily Basis of Meaning, Imagination and Reason. Chicago IL: Chicago University Press.

Ronald W. LANGACKER, 1987: Foundations of Cognitive Grammar, Vol. I. Theoretical Prerequisites. Stanford, CA: Stanford University Press.

Seth LINDSTROMBERG, 1997: English Prepositions Explained. Amsterdam/ Philadelphia: John Benjamins Publishing Company. 
Andrzej MARKOWSKI, Ed., 2006: Wielki słownik poprawnej polszczyzny PWN. Volume A-P. Warszawa: PWN.

John O'KEEFE, 1999 (1996): The Spatial Prepositions in English, Vector Grammar, and the Cognitive Map Theory. Language and Space. Ed. P. Bloom, M. A. Peterson, L. Nadel, M. F. Garrett. Cambridge, Massachusetts/London, England: The MIT Press. 277-316.

Renata PRZYBYLSKA, 2002: Polisemia przyimków polskich w świetle semantyki kognitywnej. Kraków: Universitas.

Stanisław SZOBER, 1969: Słownik Poprawnej Polszczyzny. 7th edition. Warszawa: Państwowy Instytut Wydawniczy.

Leonard TALMY, 2003 (2000): Toward a Cognitive Semantics. Volume I. Concept Structuring Systems. Cambridge, Massachusetts/London, England: The MIT Press.

Andrea TYLER, Vyvyan EVANS, 2003: The Semantics of English Prepositions. Spatial Scenes, Embodied Meaning and Cognition. Cambridge: Cambridge University Press.

Jean YATES, 1999: The Ins and Outs of Prepositions. New York: Barron's.

Cornelia ZELINSKY-WIBBELT, 1993: Interpreting and translating prepositions: A cognitively based formalization. The Semantics of Prepositions. From Mental Processing to Natural Language Processing. Ed. Cornelia Zelinsky-Wibbelt. Berlin/ New York: Mouton de Gruyter.

\section{ANGLEŠKA PREDLOGA IN TER $A T$ - USTREZNICE V IZBRANIH SLOVANSKIH PREVODIH}

Prispevek obravnava izbrane angleške besedne zveze z lokacijskima predlogoma in in at ter njune ustreznice v poljščini, češčini, slovenščini, srbščini in hrvaščini. Preprosta topološka lokacijska razmerja, ki jih angleški jezik kodira s pomočjo dveh predlogov in in at, se lahko prevajajo v slovanske jezike kot ena oblika. Prispevek se osredotoča na konstukcije, ki verbalizirajo lokacijo $v$ stavbah, idealiziranih kot tridimenzionalni objekti, ter v njim ustreznih ustanovah, idealiziranih kot nedimenzionalni objekti, prevedene $\mathrm{v}$ poljščino, češčino, slovenščino, srbščino in hrvaščino. V navedenih primerih v slovanskih jezikih ni razlikovanja med dimenzionalnostjo prostorskih prizorov. Za angleščino značilno razlikovanje med izražanjem lokacije, ki se nanaša na tridimenzionalne objekte ali na nedimenzionalne entitete, se v primerjanih slovanskih jezikih izgubi, saj se obe razmerji $v$ stavbi in $v$ ustanovi $\mathrm{v}$ poljskem, češkem, slovenskem, srbskem in hrvaškem jeziku izražata le s predlogom $v$ vsakem od navedenih jezikov ( $w$, $v, u$ ). Zato prevodi besedil $\mathrm{v}$ angleščino, ki vsebujejo besedne zveze s predlogi $w, v, u$, lahko vsebujejo napake, povezane $\mathrm{z}$ napačno interpretacijo prostorskih relacij, ki jih v angleškem jeziku definirata predloga in in at. Predlog in pomeni vsebovanje in je neločljivo povezan s pojmom POSODA, ki je eden od treh osnovnih pojmov predstavitvenih shem: STIK, POSODA, RAVNOTEŽJE. Po mnenju A. Tylerja in V. Evansa vsebovalna funkcija zajema lokaliziranje in omejevanje dejavnosti vsebovane enote. Zato raba predloga in v razmerju do samostalniških zvez, kot sta npr. gledališče ali kino, potegne za 
seboj predstavitveno shemo POSODA. Čeprav obe obliki in in at denotirata preprosta prostorska rezmerja, predlog at ni vezan na shemo POSODA, saj pred samostalniškimi zvezami kot gledališče in kino tvori prostorsko relacijo, ki v ospredje postavlja delovanje. Predložna zveza z at skupaj z nedoločnim členom $a$ ali določnim the pomeni, da se oseba nahaja na območju, npr. gledališča, znotraj ali zunaj stavbe. Če je oseba znotraj stavbe, je poudarjeno delovanje. 